J. Clin. Chem. Clin. Biochem.

Vol. 19, 1981, pp. 967-970

\title{
A New Method for the Determination of Serum Iron: Potentiostatic Coulometry with the Ferrochem 3050
}

\author{
By K. Dörner, H. Gustmann and W. Sippell
}

Abteilung Allgemeine Pädiatrie (Direktor: Prof. Dr. J. Schaub) der Universitäts-Kinderklinik Kiel

(Received October 1, 1980/January 5, 1981)

Summary: Potentiostatic coulometry allows the fast determination of iron in serum samples of $50 \mu \mathrm{l}$ serum or less. Precision, accuracy, specificity and practicability of the method were evaluated using the Ferrochem 3050 , and found to be favourable. This method can therefore be recommended to all laboratories in which small sample volumes have to be analysed.

\section{Ein neues Verfahren zur Eisenbestimmung im Serum: Potentiostatische Coulometrie mit dem Ferrochem 3050}

Zusammenfassung: Die potentiostatische Coulometrie ermöglicht eine schnelle Bestimmung von Eisen in weniger als $50 \mu \mathrm{l}$ Serum. Präzision, Richtigkeit, Spezifität und Praktikabilität des Verfahrens wurden am Ferrochem 3050 geprüft und sind als gut zu beurteilen. Die Methode ist für alle Laboratorien, denen nur geringe Probenmengen zur Verfügung stehen, zu empfehlen.

\section{Introduction}

The well-known methods for the determination of serum iron, which are based on colour reactions with bathophenanthroline disulfonate, Ferrozine ${ }^{\circledR}$ or Chromazurol $B$, require - even on a microscale - sample amounts between 0.1 and $1.0 \mathrm{ml}$ of serum $(1,2,3)$. These sample volumes are too large for paediatric purposes. Reduction of sample size is possible in flame atomic absorption spectrophotometry using an injection technique (4) or in flameless atomic absorption spectrophotometry and $\mathrm{X}$-ray fluorescence analysis (5), but both methods are not feasible for routine laboratories. A new analyser, Ferrochem 3050, developed by Environmental Sciences Associates (ESA) is based on potentiostatic coulometry and requires only a $50 \mu \mathrm{l}$ sample for serum iron determination. In addition, this analyser allows the determination of total iron binding capacity. The present study evaluates precision, accuracy and practicability of this novel method in regard to the needs of a routine laboratory.

\section{Methọds and Materials}

The evaluation was based on 100 blood donor sera and 100 sera of unselected patients in our hospital. For testing precision and accuracy, commercially available control sera (cf. table 1, 2) were used. The analyser Ferrochem 3050 (fig. 1) and all pertinent reagents were obtained from Environmental Sciences Associates, Bedford MA, USA. The principle of measurement based on potentiostatic coulometry has recently been described in detail (6).
Tab. 1. Serial precision and accuracy of the iron determination $(\mathrm{CV}=$ coefficient of variation; method 1 : Bathophenanthroline disulfonate with deproteinization; method 2: Dipyridyl).

\begin{tabular}{|c|c|c|c|c|}
\hline $\begin{array}{l}\text { Control serum } \\
\text { lot number }\end{array}$ & $\begin{array}{l}\bar{x}(s) \\
(\mu \mathrm{mol} / \mathrm{l})\end{array}$ & $\begin{array}{l}C V \\
(\%) \\
n=10\end{array}$ & $\begin{array}{l}\text { Reference values } \\
(\mu \mathrm{mol} / \mathrm{l})\end{array}$ & $\begin{array}{l}\text { Meth- } \\
\text { od }\end{array}$ \\
\hline $\begin{array}{l}\text { Monitrol I } \\
153 \mathrm{~B}\end{array}$ & $26.1(0.22)$ & 0.85 & $\begin{array}{l}26.3(23.4-29.2) \\
27.2(23.1-31.3)\end{array}$ & $\begin{array}{l}1 \\
1\end{array}$ \\
\hline $\begin{array}{l}\text { Monitrol II } \\
51 \mathrm{~B}\end{array}$ & $29.4(0.50)$ & 1.69 & $\begin{array}{l}30.6(26.7-34.5) \\
32.8(28.1-37.5)\end{array}$ & $\begin{array}{l}1 \\
1\end{array}$ \\
\hline $\begin{array}{l}\text { Precinorm U } \\
837\end{array}$ & $16.6(0.33)$ & 1.99 & $12.5(11.2-13.8)$ & 1 \\
\hline $\begin{array}{l}\text { Seronorm } \\
147\end{array}$ & $24.4(0.41)$ & 1.68 & $21.5(20.3-22.7)$ & 1 \\
\hline $\begin{array}{l}\text { Validate A } \\
0433067 \text { A }\end{array}$ & $18.7(0.48)$ & 2.56 & $15.9(12.7-19.1)$ & 1 \\
\hline $\begin{array}{l}\text { Wellcomtrol } \\
\text { K } 4384\end{array}$ & $38.8(0.48)$ & 1.24 & $36.7(34.0-39.0)$ & 2 \\
\hline
\end{tabular}

Tab. 2. Day to day precision of the iron determination using two different control sera $(\mathrm{CV}=$ coefficient of variation).

\begin{tabular}{llll}
\hline $\begin{array}{l}\text { Control serum } \\
\text { lot number }\end{array}$ & $\begin{array}{l}\overline{\mathrm{x}}(\mathrm{s}) \\
(\mu \mathrm{mol} / \mathrm{l})\end{array}$ & $\begin{array}{l}\mathrm{CV} \\
(\%)\end{array}$ & $\mathrm{n}$ \\
\hline $\begin{array}{l}\text { Monitrol I } \\
153 \mathrm{~B}\end{array}$ & $26.6(1.64)$ & 6.1 & 47 \\
$\begin{array}{l}\text { Monitrol II } \\
\text { 51 B }\end{array}$ & $34.0(1.56)$ & 4.59 & 43 \\
\hline
\end{tabular}




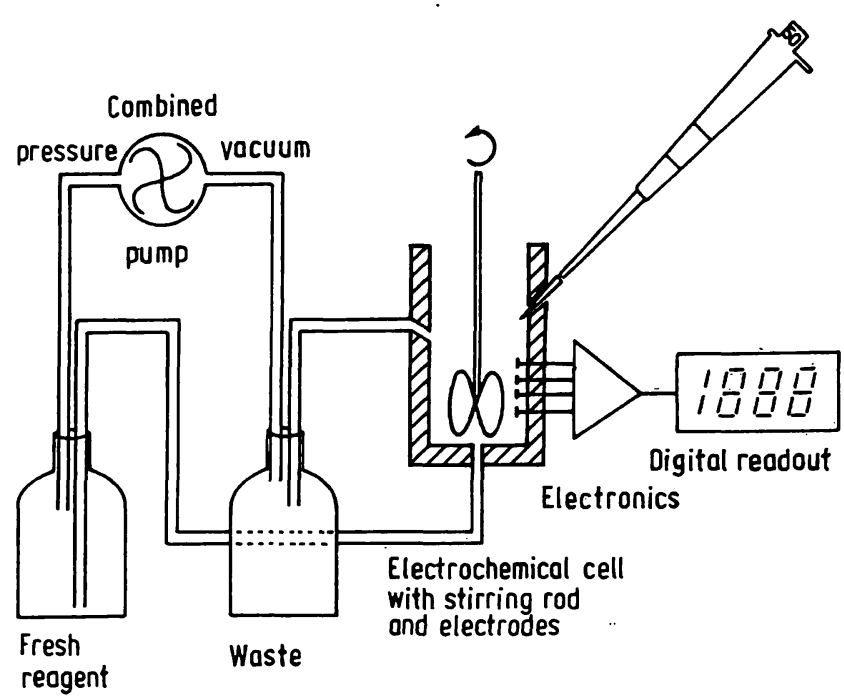

Fig. 1. Block diagram of the Ferrochem 3050 system.

The electrochemical cell contains four electrodes:

1. Test electrode 1 (cathode 1): This potential is set at $+460 \mathrm{mV}$ versus the reference electrode.

2. Electrode 2 (cathode 2): This potential is set at $+250 \mathrm{mV}$ versus the reference electrode.

3. The silver/silver chloride reference electrode.

4. The counter electrode (anode) without controlled potential. This voltage varies between $+500 \mathrm{mV}$ to $+900 \mathrm{mV}$ and depends on the conductivity of the electrolyte.

At cathode 1 both the reduction of $\mathrm{Cu}^{2+} \rightarrow \mathrm{Cu}^{+}$and the oxidation of $\mathrm{Fe}^{2+} \rightarrow \mathrm{Fe}^{3+}$ occur (opposite current!). At cathode 2 the reductions of $\mathrm{Cu}^{2+} \rightarrow \mathrm{Cu}^{+}$and $\mathrm{Fe}^{3+} \rightarrow \mathrm{Fe}^{2+}$ occur. By electronic subtraction of this charge transfer by cathode 1 and cathode 2 a compensation of the copper signal is performed, and the signals of $\mathrm{Fe}^{3+}$ and $\mathrm{Fe}^{2+}$ are added.

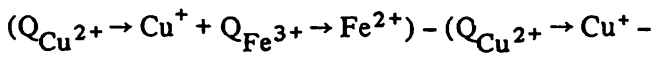

$$
\begin{aligned}
& \left.-\mathrm{Q}_{\mathrm{Fe}^{2+}} \rightarrow \mathrm{Fe}^{3+}\right)=\mathrm{Q}_{\mathrm{Fe}^{3+}} \rightarrow \mathrm{Fe}^{2+}+\mathrm{Q}_{\mathrm{Fe}^{2+} \rightarrow \mathrm{Fe}^{3+}}
\end{aligned}
$$

In order to evaluate the interference by $\mathrm{Cu}^{2+}$, increasing concentrations of copper in $100 \mu \mathrm{l}$ aqueous solution were added to $1 \mathrm{ml}$ pool serum.

According to the manufacturer, the electroly te solution consists of $236 \mathrm{~g} / \mathrm{kg} \mathrm{HCl}$ and $304 \mathrm{~g} / \mathrm{kg}$ propanol. $2 \mathrm{mmol} / \mathrm{l} \mathrm{AgCl}$ and traces of bismuth are additives found by our own analyses.

For comparative spectrophotometric tests, bathophenanthroline disulfonate (Testkit No. 548195, manufactured by Asid, Munich test volume $700 \mu \mathrm{l}$ ) and Ferrozine ${ }^{\circledR}$ (Testkit No. 0710598, manufactured by Roche, Grenzach, test volume $600 \mu \mathrm{l}$ ) were used. To determine total iron binding capacity, we used prepared testcups, manufactured by Environmental Sciences Associates containing $200 \mu \mathrm{l}$ buffer solution and iron-charged ion exchanger. $100 \mu \mathrm{l}$ serum were added into the prepared testcups. The transferrin of the sample is thus saturated by iron. By measuring the iron concentration in the buffer/serum mixture it is therefore possible to determine the total iron binding capacity. As a comparative method for total iron binding capacity, Ramsey's method (7) (Testkit No. 548195, manufactured by Asid, Munich) was used. In this procedure, scrum transferrin is saturated by $\mathrm{FeCl}_{3}$. The excess iron is absorbed by adding magnesium carbonatc. The resulting concentration of iron is then analysed spectrophotometrically with bathophenanthroline disulfonate. All statistical calculations were based on normal distributions.

\section{Results}

\section{Precision and Accuracy}

Linearity of the new coulometric method was tested with aqueous standard solutions as shown in figure 2. Serial precision, day to day precision, and accuracy are shown in table 2 and 3 . These results were obtained with $50 \mu \mathrm{l}$ sample volume. It is also possible to make analyses

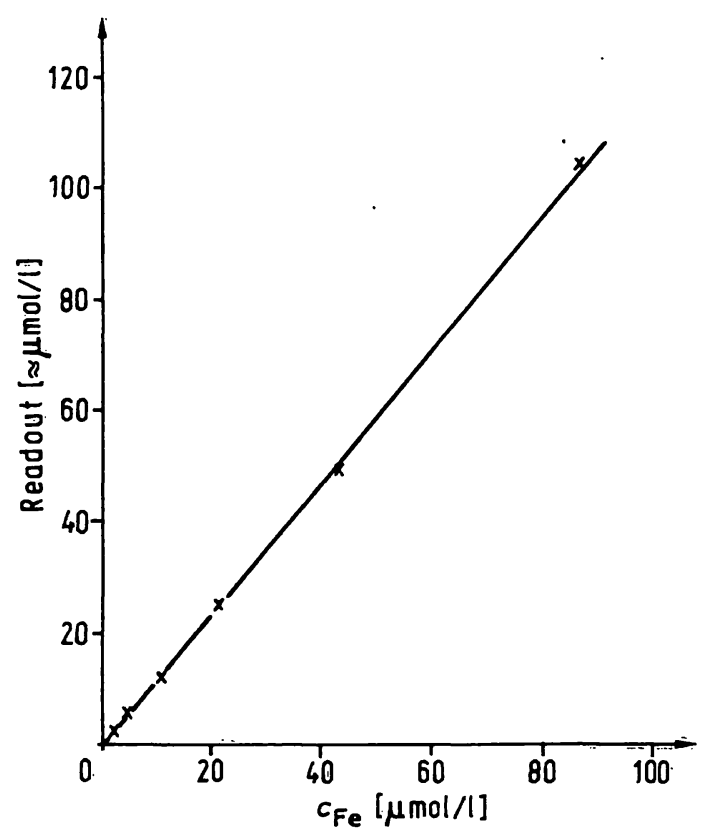

Fig. 2. Evaluation of linearity using aqueous iron solution.

with $20 \mu \mathrm{l}$, in which case, the serial precision decreases somewhat with a coefficient of variation of $2.7 \%$ $(\bar{x}=25.2 \mu \mathrm{mol} / 1, \mathrm{n}=11)$. Accuracy lies in the upper range for the method with bathophenanthroline disulfonate with deproteinization, but lower than for the same methods without deproteinization. Thus, reference values obtained by the bathophenanthroline disulfonate method may also be used for potentiostatic coulometry. Furthermore, the accuracy of this method was tested by a standard addition assay (fig. 3 ).

Tab. 3. Serial precision and accuracy of total iron binding capacity determination using the ion exchange method; reference values according to Ramsey (7).

\begin{tabular}{|c|c|c|c|}
\hline $\begin{array}{l}\text { Control serum } \\
\text { lot number }\end{array}$ & $\begin{array}{l}\bar{x}(s) \\
(\mu \mathrm{mol} / \mathrm{l})\end{array}$ & $\begin{array}{l}\text { CV } \\
(\%) \\
n=10\end{array}$ & $\begin{array}{l}\text { Reference values } \\
(\mu \mathrm{mol} / \mathrm{l})\end{array}$ \\
\hline $\begin{array}{l}\text { Monitrol I } \\
153 \mathrm{~B}^{\alpha}\end{array}$ & $58.9(3.09)$ & 5.2 & $66.8(56.8-76.8)$ \\
\hline Seronorm 147 & $68.8(4.08)$ & 5.9 & $66.9(59.0-66.0)$ \\
\hline $\begin{array}{l}\text { Wellcomtrol } \\
\text { K } 4384\end{array}$ & $68.6(3.70)$ & 3.7 & $68.0(60.0-83.0)$ \\
\hline $\begin{array}{l}\text { Validate A } \\
0433067 \text { A }\end{array}$ & $52.7(2.1 \overline{7})$ & 4.1 & $-45.7(36.6-54.8)$ \\
\hline
\end{tabular}


For analysing blood donor sera and sera of patients, we used bathophenanthroline disulfonate with deproteinization for comparison. The correlation of the results is shown in figure 4 . As can be seen, the patients' sera yield a better correlation than those from the blood donors. The reason for this is a different measurement and standardization procedure. When analysing the blood donors' sera, the blank was set after every 20

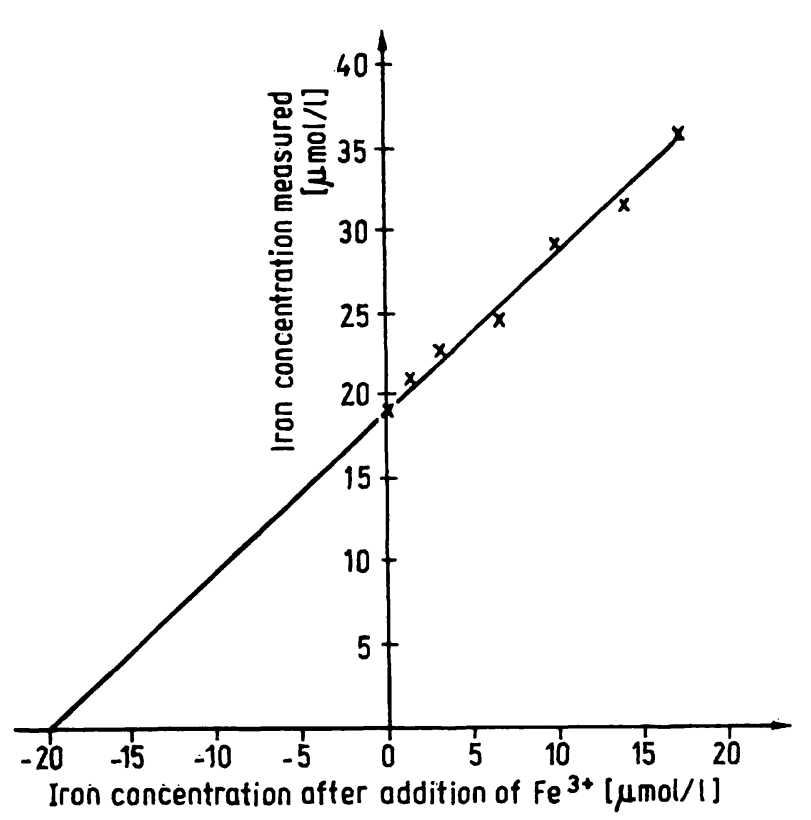

Fig. 3. Standard addition assay for evaluation of the accuracy of the coulometric method; assay: $450 \mu \mathrm{l}$ serum $+\mathrm{x} \mu \mathrm{l}$ iron solution $+(50-x) \mu l$ water.

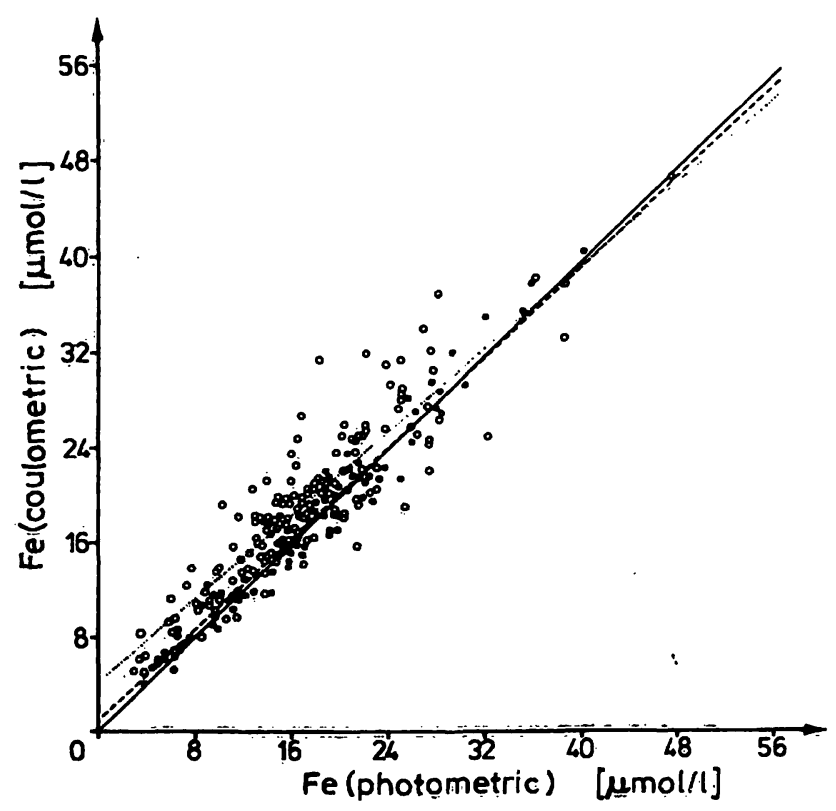

Fig. 4. Correlation between coulometric and photometric iron determination using two samples with different calibration procedures.

0 (blood donors): $y=0.887 x+4.13, r=0.900$

- (patients): $\quad y=0.967 x+0.918, r=0.976$ samples, whereas the standard calibration was checked after every 10 samples, as recommended by the manufacturer. For analysis of the patients' sera, however, the blank was set after every 10 samples, and the standard calibration after every 20 samples. Figure 5 shows the differences between the two methods plotted against the corresponding value found by coulometric analysis. In the course of these experiments, a drift of both blank

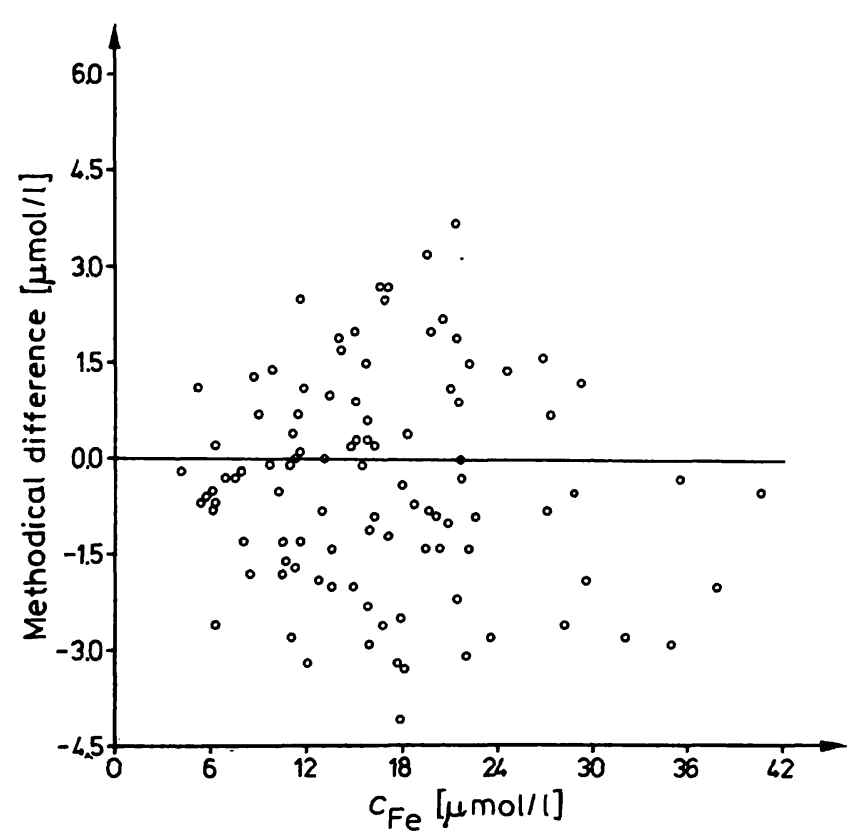

Fig. 5. Methodical differences between photometric and coulometric results in relation to iron concentration in patients' samples using coulometry.

and standard value was noted. This drift causes a parallel shift of the calibration curve to higher values, and is therefore better compensated for by blank correction than by a new standardization.

\section{Specificity}

The redox potential of $\mathrm{Cu}^{2+}\left(\mathrm{E}_{\mathrm{Cu}^{+} / \mathrm{Cu}^{2+}}=+0.17 \mathrm{~V}\right)$ is similar to that of $\mathrm{Fe}^{2+}\left(\mathrm{E}_{\mathrm{Fe}^{2+}}^{\ominus} / \mathrm{Fe}^{3+}=+0.77 \mathrm{~V}\right)$, but the Ferrochem 3050 has an electronic copper compensation, which is independent of the copper concentration, provided that the electronic adjustment is done correctly. No major disturbance by copper could be observed, i.e., variations of $\pm 16 \mu \mathrm{mol} / \mathrm{l} \mathrm{Cu}$ resulted in a difference of $\pm 3 \mu \mathrm{mol} / \mathrm{l}$ of the indicated iron concentration. Other materials with a redox potential similar to copper and iron do not exist in biological materials in concentrations that could interfere with the iron determination. In a patient treated with $3 \times 2$ dragées $(500 \mathrm{mg}$ ) salazosulfapyridine (Azulfidine ${ }^{\circledR}$ ) an erroneously high value of $>100 \mu \mathrm{mol} / \mathrm{l}$ iron was found. Similarly, haemolytic sera containing $3 \mathrm{~g} / \mathrm{l}$ haemoglobin resulted in grossly elevated iron values. 


\section{Total iron binding capacity}

Accuracy and precision of total iron binding capacity determinations are shown in table 3. For all these studies testcups manufactured by ESA were used. In a small series of 37 blood donor sera, the results of the present method compared well with those from the method according to Ramsey (7). As there were no pathological sera, a statistically normal distribution did not exist. Therefore, it was not possible to calculate a correlation coefficient. Moreover, it was found that it is possible to saturate the serum with iron according to Ramsey's (7) suggestion, to remove the excess of iron with magnesium carbonate, and to measure the iron content of the supernatant. $100 \mu$ l of serum is necessary for this kind of total iron binding capacity determination.

\section{Practicability}

A single iron determination requires about 6-15 minutes including calibration, but only 1 minute if the analyser is already calibrated. 40 samples require $1 \mathrm{~h}$. The price of a single determination amounts to about $0.66 \mathrm{DM}$ without standards. However, it is possible to prepare the reagent solution in the laboratory. The price of one single test can thus be reduced to 0.08 DM. Furthermore, it is easy to work with this analyser. The technical construction of the system makes possible to change the bottles with the chemically aggressive reagent with no hazard to the operator. There was one technical defect during the six months of work with the analyser, which was corrected by an electronic re-adjustment of the system by the service engineer.

\section{Discussion}

In clinical laboratories, coulometry is not yet used for iron determination. The efficiency of this new method was compared with the well-known spectrophotometric method which uses bathophenanthroline disulfonate. This reagent has also been recommended as a chelating agent by the International Committee of Standardization in Haematology (ICSH). Precision of the new method was at least equivalent to those reported by other authors $(1,2,8)$ (table $1-3)$. In our opinion, it is most important that the results obtained for patients' sera, using the Ferrochem 3050 and the bathophenanthroline disulfonate method, should be the same. This was demonstrated to be the case for several commercially available control sera and the sera of blood donors and patients. For obtaining correct results, it was necessary to check and correct the blank and the standard after every 10 samples, owing to analyser drift. This drift might be caused by alterations at the surface of the electrodes during the determinations. In the manufacturer's manual this phenomenon is called a "serum jump", which is said to be found with new and badly conditioned electrodes only.

Compounds containing an azo group $(-\mathrm{N}=\mathrm{N}-)$ interfere with the coulometric iron analysis, resulting in erroneous iron values. The only drug of this type being widely used in this country is, to our knowledge, salazosulfapyridine (Azulfidine ${ }^{\circledR}$ ).

The important advantage of the new method is its small sample volume of only $50 \mu \mathrm{l}$ serum. It is also possible to make analyses even with $20 \mu \mathrm{l}$ serum. The results from the Ferrochem 3050 are obtained much more quickly than with comparative methods. These advantages are impaired by the high costs when the electrolyte mixture has to be purchased from the manufacturer and is not prepared in the laboratory. As sera and standards have to be pipetted manually, this method seems to be better for short and intermediate than for long series.

The chemical determination of total iron binding capacity can also be performed by the Ferrochem 3050, if the iron excess after saturation of transferrin is removed in neutral or weak acid solution, or if the saturation of transferrin is achieved by an iron-charged ion exchanger.

\section{Acknowledgements}

The authors thank the staff members of the Department of Immunohaematology and Blood Transfusion (Direktor: Prof. Dr. Sachs), Kiel University, School of Medicine, for providing sera for analyses.

The use of the computer facilities of the Department of Paediatric Cardiology (Direktor: Prof. Dr. Heintzen), Kiel University, School of Medicine, for the statistical calculations is gratefully acknowledged.

\section{References}

1. Koch, C.-D., Woehrmann, W. \& Ritter, U. (1974) Z. Klin. Chem. Klin. Biochem. 12, 508-514.

2. Hagemann, P., Meier, K. \& Meier, Margrit (1978) Med. Lab. 31, 95-99.

3. Garĉic, A. (1979) Clin. Chim. Acta 94, 115-119.

4. Berndt, H. \& Jackwerth, E. (1979) J. Clin. Chem. Clin. Biochem. 17, 489-494.

5. Knoth, J., Schwenke, H., Marten, R. \& Glauer, J. (1977) J. Clin. Chem. Clin. Biochem. 15, 537-560.

6. Mack, B. (1980) GIT 3, 377-378.

7. Ramsay, W. N. M. (1957) Clin. Chim. Acta 2, 221-226.

8. International Committee for Standardization in Haematology (1978) Brit. J. Haematol. 38, 291-294.

9. Lauber, K. (1978) J. Clin. Chem. Clin. Biochem. 16, 315316.

PD Dr. Dr. K. Dörner Universitäts-Kinderklinik Schwanenweg 20 D-2300'Kiel 